\title{
MOLECULAR AND SEROEPIDEMIOLOGIC STUDIES OF ENTEROVIRUS 71 INFECTION IN THE STATE OF PARÁ, BRAZIL
}

\author{
Ceyla M.o. CASTRO(1), Ana Cecília R. CRUZ(2), Edson E. DA SILVA(1) \& Maria de Lourdes C. GOMES(2)
}

\begin{abstract}
SUMMARY
In many countries, the Enterovirus 71 (EV-71) Picornaviridae family is associated to hand, foot and mouth disease in addition to acute neurological diseases while in Brazil these viruses are more closely associated to the latter group. The aim of this research was to use the first EV-71 isolate of the Northern region of Brazil in molecular and seroepidemiologic studies. Two (2.2\%) out of 88 stool samples (44 cases of AFP), collected from January 1998 to December 2000 were positive for EV-71 isolation (73442/PA/ 99). Nucleotide sequence of the gen that codifies the VP1 protein showed that isolate $73442 / \mathrm{PA} / 99$ was similar to the EV-71 strains belonging to genotype B - more closely identified with EV-71 from North America. Neutralization test with 389 sera samples collected from January 1998 to November 2001, from individuals ranging from 0 to 15 years of age living in the city of Belém, State of Pará showed the following results in relation to isolate 73442/PA/99 and prototype BrCr: a total of 207 individuals (53.2\%) had neutralization antibodies to both viruses, 167 (42.9\%) had no antibodies and 15 showed the presence of neutralizing antibodies to one of the two viruses. Only $20.2 \%$ of the children aged 0 to 3 had neutralizing antibodies to EV-71, indicating that these children were more susceptible to the infection. Both the seroprevalence study and VP1 sequencing were important to demonstrate the spread and the molecular pattern of the EV-71 circulating in the Northern Region of Brazil.
\end{abstract}

KEYWORDS: Enterovirus 71; Acute flaccid paralysis; Neutralizing antibodies.

\section{INTRODUCTION}

Enterovirus 71 (EV-71) was identified for the first time in 1974 by SCHMIDT et al. ${ }^{30,31,36}$. This virus is associated to sporadic cases and epidemics of hand, foot and mouth disease (HFMD), acute neurological diseases such as aseptic meningitis, encephalitis and poliomyelitic syndrome as acute flaccid paralysis ${ }^{3,36,44}$. The importance of this virus increased after a large epidemic occurred in two countries of Eastern Europe where poliomyelitis had been controlled. The first epidemic occurred in 1975, in Bulgaria with 705 registered cases, of which 149 were paralysis and 44 were fatal cases. The second one occurred in Hungary in 1978, with 1550 patients, of whom 826 had aseptic meningitis and 724 had encephalitis. Forty-five fatal cases were registered $^{11,33,38}$. EV-71 was also the most important virus responsible for outbreaks of acute neurological disease in Southern Sweden ${ }^{3}$, Australia $^{16,24,28}$, Asia $^{23,35,40,41}$ and the United States ${ }^{2,9,20}$. More recently this virus was responsible for fatal cases in the 1997 HFMD outbreak in Malaysia ${ }^{27}$ and for an extensive outbreak of HFMD in Taiwan in 1998 in which 405 children were hospitalized. From these, 78 died due to paralysis with pulmonary edema ${ }^{7,22,26}$.

The first evidence of EV-71 infection in Brazil was associated to acute flaccid paralysis (AFP) cases that occurred in Distrito Federal and States of Piauí, Goiás and Bahia with $32.1 \%(9 / 28)$ of sera displaying increase in neutralizing antibodies ( $\mathrm{NtAb})$ titers to this virus $^{12}$. Studies have been also reported ${ }^{15,42}$ mentioning EV-71 isolation.

A rapid clinical deterioration and death was observed among children with encephalitis during an HFMD epidemic caused by EV71. Studies have indicated that the severity of the infections caused by EV-71 was at least partly dependent on the strain responsible for each epidemic $^{37}$. Knowledge is still scarce regarding the determinant of virulence and antigenic alterations of EV-7139.

EV-71 posses a single strand positive polarity RNA genome with approximately $7.5 \mathrm{~kb}^{32}$. The viral capsid is constituted by four structural proteins (VP1, VP2, VP3 and VP4). The epitopes responsible for antibody induction are located in VP1, VP2 and VP3. The majority of the epitopes grouped in VP1 which is apparently more exposed, becoming this region extremely antigenic ${ }^{34}$.

The aim of this research was to use the first EV-71 isolate in the Northern region of Brazil in molecular and seroepidemiologic studies.

\section{MATERIAL AND METHODS}

Specimen collection and processing. Group A: Eighty-eight stool samples collected from 44 cases of AFP in the State of Pará from 
January 1998 to December 2000 were used for viral isolation. A 20\% fecal suspension was prepared in $8 \mathrm{~mL}$ of Hank's BSS and $2 \mathrm{~mL}$ of antibiotic and fungicid. Group B: serum samples were collected from 389 patients of both sexes, aged from 0 to 15, attended at the Virology Section of Evandro Chagas Institute, with symptomathology of Rubeola. The samples ( 5 or $10 \mathrm{~mL}$ of blood from each patient according to age), were obtained from January 1998 to November 2001. The individuals lived in 31 of the 48 districts of the city of Belém, State of Pará.

Cell lines and virus isolation: An RD cell line (embryonic human rhabdomyosarcoma) from the Centers for Disease Control (CDC) was used to conduct viral isolation. This cell was maintained in Eagle's MEM with Earle's salts, L-Glutamine non essential amino acid and with no Sodium bicarbonate. A volume of $200 \mu \mathrm{L}$ of fecal suspension was inoculated onto RD. The tube was incubated at $36{ }^{\circ} \mathrm{C}$ and observed during the $3^{\text {rd }}, 5^{\text {th }}$ and $7^{\text {th }}$ days. Blind passage was conducted to isolate the virus.

RNA extraction and RT-PCR: RNA was extracted from RD cellular fluid using Trizol reagent (Life Technologies) and chloroform and precipitate with isopropanol, according to the methodology of CHOMCZYNSKI \& SACCHI ${ }^{8}$. The purified RNA was suspended in 10-20 $\mu \mathrm{L}$ of nuclease free water. The recommendation of BROWN et al. was followed in RT-PCR, with minor modifications ${ }^{5,6}$. In the first mix, 30 pmol of each primer (Table 1) were mixed with $4 \mu \mathrm{L}$ of water and $3 \mu \mathrm{L}$ of RNA. This mixture was denatured at $95^{\circ} \mathrm{C}$ for five minutes. Next, this was added to the following $40 \mu \mathrm{L}$ of the second mixture: $100 \mu \mathrm{M}$ concentration of each deoxynucleoside triphosphate, $2 \mathrm{mM}$ $\mathrm{MgCl}_{2}, 67 \mathrm{mM}$ Tris-HCl (pH 8.8), $17 \mathrm{mM}$ (NH4)2SO4, $1 \mathrm{mM} \beta$ mercaptoethanol, $0.2 \mathrm{mg}$ of gelatin per $\mathrm{mL}, 10 \mathrm{U}$ of placental Rnase inhibitor (Gibco BRL), 12 U of Super Script reverse transcriptase (GiboBRL) and $5 \mathrm{U}$ of $\mathrm{Taq}$ polymerase (Gibco-BRL) following an incubation for $30 \mathrm{~min}$, at $42{ }^{\circ} \mathrm{C}$ for cDNA synthesis and $3 \mathrm{~min}$. at $94{ }^{\circ} \mathrm{C}$ for RT inactivation. This mixture was submitted to 35 cycles of denaturation $\left(94{ }^{\circ} \mathrm{C} 30 \mathrm{sec}\right)$ annealing $\left(42{ }^{\circ} \mathrm{C} 30 \mathrm{sec}\right)$ and extension $\left(68{ }^{\circ} \mathrm{C} 2 \mathrm{~min}\right)$. The products were submitted to eletrophoresis in agarose $1 \%$ gel in the presence of ethidium bromide and visualized by U-V illumination.

Sequencing of PCR products: DNA products were purified with Concert Rapid Gel Extraction System (Gibco-BRL) in accordance with manufacturer's instructions. The sequences were determined by cycle sequencing reaction using Big Dye Terminator Cycle Sequencing Ready Reaction Kit (Applied Biosystems, USA) and the products analyzed on an automatic ABI PRISM 377 DNA Sequencer (Applied Biosystems). Each DNA fragment was sequenced in both directions to avoid nucleotide ambiguity. The nucleotide VP1 region sequence was edited in the BioEdit program ${ }^{19}$. Multiple alignment was obtained in the Clustal X program version $1.8^{21}$. The dendogram was constructed by neighbor-joining method using the Mega 2.0 software $^{25}$ in accordance with Kitamura 2 parameter.

Neutralization microtechnique. The WHO protocol preconized for polioviruses ${ }^{45}$ was adopted in this procedure with some modifications. Sera samples $(200 \mu \mathrm{L})$ were inactivated at $56{ }^{\circ} \mathrm{C} 30$ minutes and diluted to $1: 8$ in $1400 \mu \mathrm{L}$ of Eagle's MEM. Subsequent dilution was conducted on a microplate. A volume of $50 \mu \mathrm{L}$ of the dose challenge (100 TCID50/.05 mL) was added to the entire sera dilution. The control related to the viral dose as well as the cell were included. The following incubation period was adopted: two hours at $37{ }^{\circ} \mathrm{C}$ in $\mathrm{CO} 2$ incubator followed by $4{ }^{\circ} \mathrm{C}$ over night. The last step was the addition of $100 \mu \mathrm{L}$ of $\mathrm{RD}$ cell suspension $2 \times 10^{-5} \mathrm{cel} / \mathrm{mL}$. Microscope observations were conducted on the $5^{\text {th }}$ and $7^{\text {th }}$ days.

Statistical analysis. The calculation concerning sample size and division for age band were conducted using the software Epi-Info 6.0 version, Centers for Disease Control, Atlanta, GA (USA) ${ }^{14}$. The classic concept of epidemiology descriptive for selection, evaluation and comparison of diagnostic methods ${ }^{43}$ was used to define sensitivity, specificity and other terminology.

\section{RESULTS}

Identification of EV-71. Two (2.2\% of the total samples) out of 88 stool samples (44 AFP cases) were positive for EV-71. Other Enterovirus serotypes as well as unidentified virus and Adenoviruses were also isolated (data not shown). The two EV-71 positive samples (73442/PA/99 Stool 1 and 2) were collected from a 15-month-old patient who presented AFP, living in the "Santana do Araguaia" region located in southern Pará. When this patient was examined six months later, she had suffered no relapse.

Viral isolation was possible after two successive passes in RD. CPE was observed on the third day after the second pass. Amplified

Table 1

Oligonucleotide primers used for RT-PCR and sequencing

\begin{tabular}{lll}
\hline Primer & Sequence 5'-3' & $*$ Nucleotide \\
\hline B449 (+) PCR/Sequencing & GAT GGA GTG TTC GAC TAC TAT ACC & $2262-2285$ \\
B450 (-) PCR/Sequencing & GTT AAG AAC GCA TCG TGT CTC & $2654-2634$ \\
195 (+) PCR/Sequencing & GTT CTT AAC TCA CAT AGC ACA GC & $2646-2668$ \\
172 (+) Sequencing & TTC AGT AGG GCA GGC TTG GTA GG & $2691-2714$ \\
$204(-)$ Sequencing & CTG CTG AAG AAA CTA TCG AGA G & $2698-2679$ \\
93 (-) Sequencing & ACI TCI CCI GTA GGI GGI GTA CA & $2879-2859$ \\
163 (+) Sequencing & GAG CAC AAG CAG GAG AAA GAC C & $3078-3100$ \\
$154(-)$ PCR/Sequencing & CAC TCC TGT TTG ACA ATT GCA AC & $3500-3478$ \\
\hline
\end{tabular}

*Position on the genome of EV-71 strain 7423/MS/87 (Brown \& Pallansch, 1995). 
products in size correspondent to EV-71 were observed in RT-PCR. The products $392 \mathrm{bp}$ and $854 \mathrm{bp}$ (Fig. 1) were used in the sequencing of isolate $73442 / \mathrm{PA} / 99$.

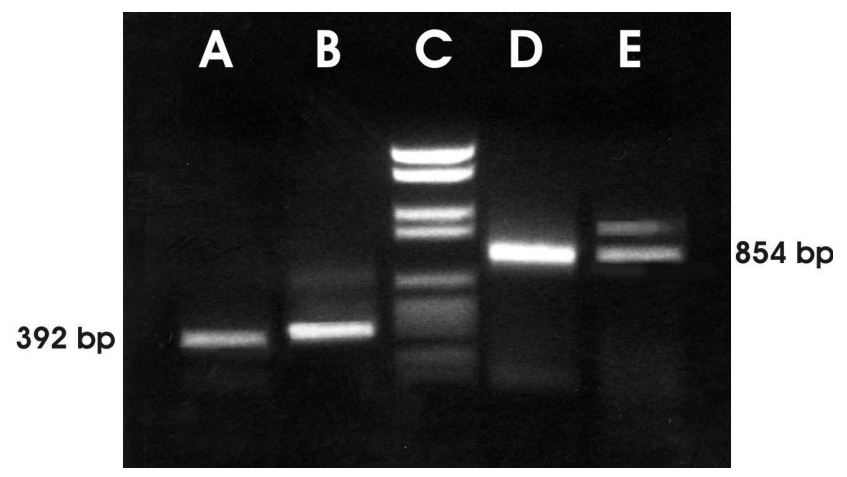

Fig. 1 - Agarose gel 1\% showing the products obtained in RT-PCR using isolate 73442/PA/ 99 and positive control (prototype strain $\mathrm{BrCr}$ ). Line A = fragment 392bp (73442/PA/99); Line $\mathrm{B}=$ fragment $392 \mathrm{bp}$ (prototype strain $\mathrm{BrCr}$ ); Line $\mathrm{C}=$ molecular weight $154 \mathrm{bp}$ (Boehringer Mannheim); Line D = fragment 854bp (73442/PA/99); Line E = fragment 854bp (prototype $\mathrm{BrCr}$ ).
Sequencing of VP1 gene of the 73442/PA/99 isolate. This study analyzed $891 \mathrm{bp}$ of the VP1 region, major protein of the EV-71 capsid of the first isolate (73442/PA/99) from the northern region of Brazil. Twenty-seven EV-71 strains and the CoxA16-G10 strain (Table 2) were used in the comparative analyses s, $^{5,37}$.

According to BROWN et $a l^{5}$., there are three different EV-71 genotypes: A, B and C. Although isolate 73442/PA/99 shows high genetic affinity with the strains belonging to the B genotype, the Brazilian isolate has formed a separate lineage within this genotype (Fig. 2).

In the comparative analysis of the VP1 region nucleotide sequence, isolate $73442 / \mathrm{PA} / 99$ had $79 \%$ of homology with prototype strain $\mathrm{BrCr}$ belonging to genotype A. The degree of homology of isolate 73442/PA/ 99 with strains of the genotype B ranged from 87\% (strains AUS74-2 and SAR00) to $91 \%$ (strains 7423/MS/87, CA86 and CA87). The strains of the genotype C were $81 \%$ homologous to isolate $73442 / \mathrm{PA} / 99$. Nucleotide identity was $52 \%$ when compared to the CoxA16-G10 strain.

In relation to the amino acid sequence, isolate 73442/PA/99 presented $93.9 \%$ similarity to the prototype strain $\mathrm{BrCr}$ (genotype A).

Table 2

Strains used in molecular analysis

\begin{tabular}{|c|c|c|c|c|}
\hline Strain & GenBank accession no. & Year of isolation & Origin & Clinical association \\
\hline $\mathrm{BrCr}$ & U22521 & 1970 & California & Encephalitis \\
\hline Nagoya/73 & AB059813 & 1973 & Japan & Hand foot mouth disease \\
\hline AUS74 & AF135886 & 1974 & Australia & Meningitis \\
\hline AUS74-2 & AF135884 & 1974 & Australia & Meningitis \\
\hline 258/BULG75 & AB059814 & 1975 & Bulgary & Encephalitis (death) \\
\hline NY77 & AF135877 & 1977 & New York & NA \\
\hline NY77-2 & AF135871 & 1977 & New York & NA \\
\hline NY77-3 & AF135874 & 1977 & New York & NA \\
\hline HUNG78 & AB059815 & 1978 & Hungary & Encephalitis (death) \\
\hline UT82 & AF135891 & 1982 & Utah & NA \\
\hline UT83 & AF135894 & 1983 & Utah & NA \\
\hline OH82 & AF135892 & 1982 & Ohio & Exanthem \\
\hline MA82 & AF135893 & 1982 & Massachusetts & Encephalitis \\
\hline CHN85 & AF135934 & 1985 & China & Hand foot mouth disease \\
\hline CA86 & AF009525 & 1986 & California & AFP \\
\hline CA87 & AF009527 & 1987 & California & AFP \\
\hline WA87 & AF009526 & 1987 & Washington & Meningitis \\
\hline PA87 & AF009537 & 1987 & Pennsylvania & NA \\
\hline PA87-2 & AF009524 & 1987 & Pennsylvania & NA \\
\hline 7423/MS/87 & U22522 & 1987 & Mississipi & AFP \\
\hline COL94 & AF135899 & 1994 & Colombia & AFP \\
\hline AUS95 & AF135947 & 1995 & Australia & Hand foot mouth disease \\
\hline MAA97 & AF135911 & 1997 & Malaysia & NA (death) \\
\hline MAA97-2 & AF135935 & 1997 & Malaysia & NA \\
\hline AUS99 & AF376110 & 1999 & Australia & Cerebellar ataxia \\
\hline AUS99-2 & AF376106 & 1999 & Australia & Meningitis \\
\hline SAR00 & AF376083 & 2000 & Sarawak & Hand foot mouth disease \\
\hline CoxA16-G10 & U05876 & 1951 & South Africa & NA \\
\hline
\end{tabular}

$\mathrm{NA}=$ not available 
When compared to genotype B, this value ranged from 97.6 to $99.3 \%$, while with strains of genotype $\mathrm{C}$ the degree of similarity ranged from 95.9 to $97.3 \%$. This similarity decreased to $72.3 \%$ when compared to strain CoxA16-G10. This high degree of similarity shows that the majority of nucleotide substitutions was synonym and has mainly occurred in the third base of each codon.

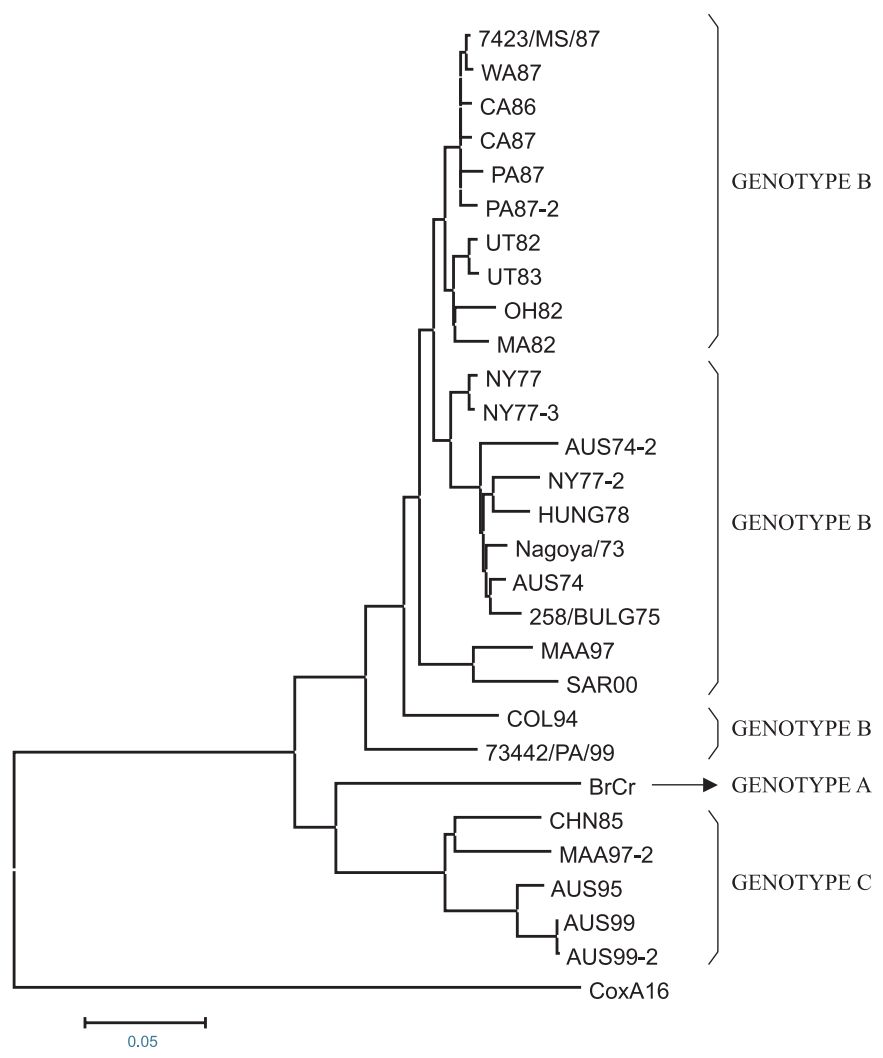

Fig. 2 - Dendrogram showing the genetic affinity of isolate 73442/PA/99 with strains of EV71 and strain Cox A16-G10, based on alignment of VP1 gene nucleotide sequence ( $891 \mathrm{bp}$ ).

Detection of EV-71 NtAb. Figure 3 shows the results of the neutralization test with the 389 sera, isolate $73442 / \mathrm{PA} / 99$ and prototype strain BrCr. From the 389 sera, 207 (53.2\%) had NtAb to the isolate and to the prototype, while 167 (42.9\%) had no NtAb. Fifteen (3.8\%) had $\mathrm{NtAb}$ to one or the other. According to the age of the patients, we can observe that $79.7 \%(79 / 389)$ of the children up to three years had no NtAb for both EV-71, while 20.2\% (20/389) had NtAb. In the three remaining age groups (4-7, 8-11 and 12-15 y), this percentage changed considering that the number of individuals with $\mathrm{NtAb}$ was superior to that without these antibodies.

Regarding to sex, no significant frequency was observed in the detection of $\mathrm{NtAb}$ (data not shown).

Figure 4 shows the neutralizing antibodies levels in the sera of the individuals. We can observe that NtAb to isolate 73442/PA/99 and to prototype strain in the levels $<1: 8$ and $>1: 256$ were similar. In the intermediary levels 1:8 - 1:32 and 1:64 - 1:256, 28 and 26 sera respectively, showed discrepancy in relation to both viral samples.

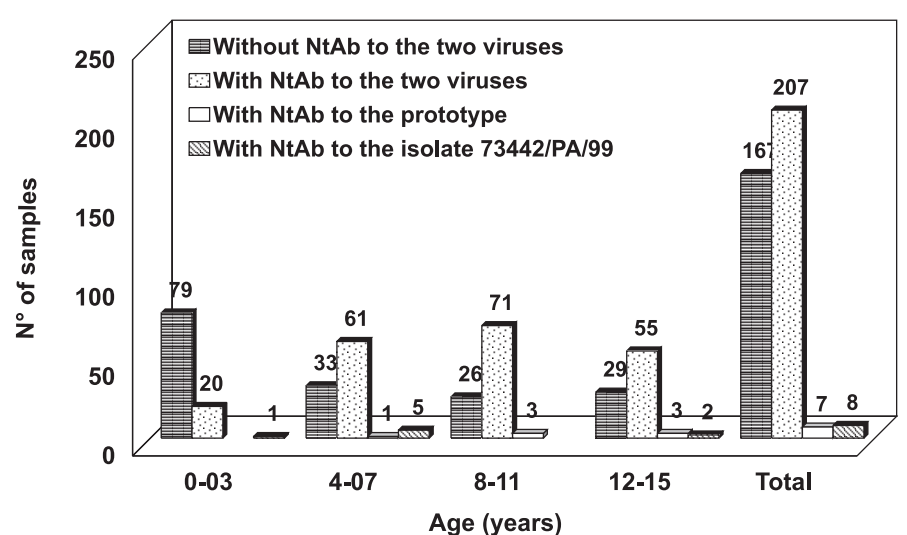

Fig. 3 - Neutralizing antibodies to EV-71 in sera of individuals living in Belém, Brazil, according to age.

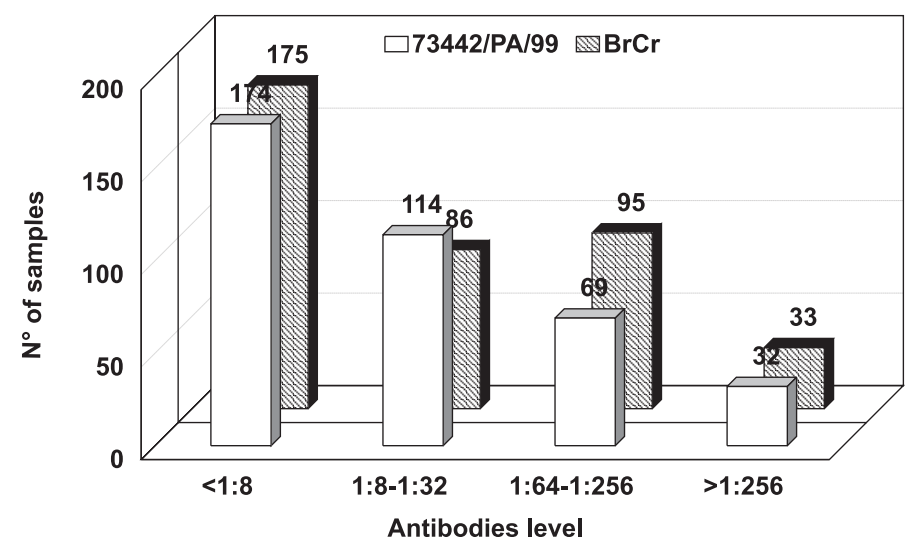

Fig. 4 - Neutralizing Antibodies levels to EV-71 observed in the 389 sera samples of individuals living in Belém, Brazil.

These results demonstrate a concordance of $96.1 \%$. Specificity was $100 \%$ considering that 167 sera were negative to both viral samples. The fact that 15 sera presented antibodies only to one of the viruses expresses a sensitivity of $93.2 \%$. The percentage of false negatives was seven. There were no false positives. The positive and negative predictive values were $100 \%$ and $97.1 \%$ respectively.

Concerning the 31 districts where the individuals live, eight presented a prevalence of $\mathrm{NtAb}$ superior to $50 \%$. These districts were the following: Telégrafo 75\%, Fátima 69.2\%, Marco 59.6\%, Campina de Icoaraci 58.3\%, Montese 57.9\%, Umarizal 57.1\%, Guamá 52.4\% and Marambaia 51.2\%.

\section{DISCUSSION}

The results of this study demonstrate a low percentage of positive samples to EV-71. This may suggest a low association of these viruses to AFP cases in the State of Pará and in the Northern Brazil since the isolate 73442/PA/99 was the first in this region, even though we have been monitoring the occurrence of the AFP cases in the region for several years. The low percentage of isolation of these viruses could also be due to the use of the technique adopted by the $\mathrm{WHO}^{45}$ within the Polio eradication program, which recommends the use of two 
passages in cell culture for each fecal specimen from AFP cases, which is adequate for poliovirus isolation. Considering that many samples of EV-71 show a slow progression of CPE, often multiple passes may be necessary to isolate this virus.

This low frequency of EV-71 isolation has been mentioned by TAKIMOTO et al. $^{42}$ analyzing 426 children aged 0 - 15 years who presented acute neurological disease including AFP occurring in São Paulo and Brasília. They isolated EV-71 in 17 cases which represents $3.9 \%$ of the total. In a study reported by NAGY et al. ${ }^{33}$ focusing on a large epidemic of acute neurological disease that occurred in Hungary in 1978, in which EV-71 was the virus responsible, viral isolation was obtained in $2.6 \%$ representing 52 isolations from a total of 1952 clinical samples.

Studies involving detection of NtAb to EV-71, in other countries as well as in Brazil, are scarce. Serologic studies of specific occurrence such as cases of HFMD ${ }^{40,41}$, acute neurological diseases such as meningitis and encephalitis ${ }^{11,33,38}$ and AFP in particular ${ }^{12,13,42}$ have been reported. These studies emphasize recent infections of EV-71 using sera from acute and convalescent phase (seroconversion) in seroneutralization test or detection of IgM antibodies.

In order to obtain data on EV-71 circulation, part of this study was directed to detection of $\mathrm{NtAb}$ against EV-71 in sera from individuals of ages up to 15 years living in Belém, Brazil.

In the present study, $52.4 \%$ of the children up to 11 years had $\mathrm{NtAb}$ to both viral samples of EV-71 (prototype strain $\mathrm{BrCr}$ and isolate 73442/PA/99), showing circulation of this virus in Belém, predominantly in the 8-11 years age group, as mentioned before (Fig. 3). In Japan, a prevalence study of NtAb to EV-71 among healthy children up to 11 years of age in the city of Kawasaki showed that nine (6.6\%) out of 137 sera collected had NtAb to EV-71 ${ }^{18}$. The difference between the two studies was the utilization of $\mathrm{CMK}^{1}-\mathrm{S}^{1}$ (cell culture derived from Cynomolgus monkey kidney) in the Japanese study and RD in our study. We cannot conclude regarding the influence of this variable in the different results obtained in both studies.

In previous studies using prototype strain $\mathrm{BrCr}$ as antigen we found that, in a group of 238 individuals of up to 15 years of age, living in Belém, Brazil, $40.7 \%$ had NtAb to this virus. From the 97 positive sera, $75(77.3 \%)$ presented significant titer levels that ranged from 1:8 to $1: 256^{17}$. Similar results were found in the present study: $84.5 \%(181)$ from the 214 positive samples presented $\mathrm{NtAb}$ titer to the prototype strain ranging from 1:8 to $1: 256$ in the same age group. Similar results were observed $(85.1 \%$ - 183/215) to isolate 73442/PA/99 (Fig. 4).

In another study on infections by EV-71 associated to AFP cases in Brazil, the level of antibodies in nine of the 28 paread do not exceed $1: 32$. These findings may signify that the neutralizing antibodies induced by circulating strains do not reach high antibody levels ${ }^{12}$.

We know that high demographic density facilitates close contact among people. This situation in conjunction with poor basic sanitation conditions contribute to the dissemination of diseases. In highly populated areas and where no adequate sanitation conditions exist, the prevalence of disease is high; the inverse also being true. Generally, the outlying districts of the cities are the one that display both factors. In this study, this was not always true. The district of Telégrafo, where the main prevalence of NtAb occurred has the $11^{\text {th }}$ highest demographic density $\left(17.73 \mathrm{ha} / \mathrm{km}^{2}\right)$. The district of Guamá, the most crowded of Belém, with 98.959 inhabitants and with the $3^{\text {rd }}$ highest demographic density $\left(23.97 \mathrm{ha} / \mathrm{km}^{2}\right)$, appears in seventh place in terms of NtAb prevalence. Both are located in outlying regions of the city. The lowest prevalence was observed in the Batista Campos district in the city center, which has the $13^{\text {th }}$ highest demographic density $\left(13.73 \mathrm{ha} / \mathrm{km}^{2}\right)$. Probably only one factor, poor sanitation conditions, was sufficient for viral circulation, contributing to the high prevalence of $\mathrm{NtAb}$ in the district of Telégrafo, while, in the district of Guamá, both factors were not sufficient to yield a high prevalence. We would like to emphasize that these results correspond to 389 samples of sera from spontaneous demand. Maybe a broader sample size is required to confirm these findings. The Batista Campos district has better sanitation conditions and does not have high demographic density, justifying the lower prevalence.

Reports mentioning molecular epidemiology of EV-71 strains ${ }^{1,5,10,37,39,46}$ have demonstrated the genetic heterogeneity of EV71 , which is probably associated to antigenic modifications and virulence variations leading to different symptoms observed after infection with the virus.

This study analyzed the nucleotide sequence of the VP1 region, of the first isolate of EV-71 (73442/PA/99) from northern Brazil, verifying genetic affinity of this isolate with EV-71 strains from other countries.

BROWN \& PALLANSCH${ }^{4}$ determined the genetic affinity between two EV-71 neurovirulent strains (prototype $\mathrm{BrCr}$ and 7423/MS/87). In the VP1 region, the strain $7423 / \mathrm{MS} / 87$ was $93 \%$ similar to the prototype strain $\mathrm{BrCr}$ in the amino acid sequence. The isolate 73442/PA/99 presented $91 \%$ of homology with the strain $7423 / \mathrm{MS} / 87$ in the VP1 nucleotide sequence and $98.9 \%$ of similarity in amino acid.

The dendogram presented in the Figure 2 shows that the virus isolated in the State of Pará, 73442/PA/99 and the isolated in Colombia 1994 (COL 94), constitute an independent lineage from the others grouped in genotype B. Isolate $73442 / \mathrm{PA} / 99$ is close-related to the neurovirulent strain 7423/MS/87 isolate in 1987 in the State of Mississipi and to two other samples of EV-71 isolated in California (CA 86 and CA 87). This proximity suggests that isolate 73442/PA/99 may have been derived from one of these North American viral strains, isolated approximately 12 years before the strain 73442/PA/99. The difference between isolate 73442/PA/99 and these three viral strains, within the VP1 region (9\%), suggest a rate of genomic evolution estimated at less than $1 \%$ per year, close to the evolution rate observed to the genome of the poliovirus and of EV- $71^{5}$.

BROWN et al. ${ }^{5}$ verified that the prototype strain $\mathrm{BrCr}$ was 80.3 $83.5 \%$ identical to the isolate of genotype B and C in the nucleotide sequence and 94.2 - 96.0 similar in amino acid. These values were $79 \%$ and $93 \%$ to the nucleotide and amino acid sequence, respectively for prototype strain $\mathrm{BrCr}$ and isolate 73442/PA/99.

Another investigation conducted by McMINN et al. ${ }^{29}$ shows the analysis of the nucleotide sequence of the VP1 gene of 66 EV-71 strains 
isolated in outbreaks of HFMD and encephalitis that occurred in Malaysia (Sarawak), Singapore and Western Australia in the period from 1997-2001. In the comparative analyses, isolate 73442/PA/99 presented $80-88 \%$ of nucleotide homology with 13 samples from Sarawak, isolated during the period from 1997 - 2000 and the similarity of amino acid was 96.9 - 98.6\%. Six strains from Australia (1999 2000) and nine from Singapore (1998 - 2000) were 81 - $88 \%$ identical to the Brazilian isolate in the nucleotide sequence and 96.2 to $98.6 \%$ similar in the amino acid sequence.

Our study analyzed, for the first time in Brazil, the nucleotide sequence of the entire VP1 gene of an EV-71 strain. Further studies are necessary to define the molecular and genotypic characteristics of other Brazilian isolates and their insertion within the EV-71 phylogenetic tree. The genetic pattern of these viruses may be extremely useful in monitoring viral circulation and to provide data on the molecular epidemiology of EV-71 in Brazil. Studies involving this subject are ongoing at the FIOCRUZ Enterovirus laboratory and preliminary results indicate that isolate $73442 / \mathrm{PA} / 99$, compared to a sample of EV-71 isolated in the State of Pernambuco (26725/PE/00) presents $88.7 \%$ of nucleotide homology (in the total of 309 bp sequenced of the VP1 gene). These preliminary analyses show that sample 26725/PE/00 and the isolate 73442/PA/99 formed an independent lineage (data not shown).

\section{RESUMO}

\section{Estudos soroepidemiológico e molecular de infecção por EV-71 no Estado do Pará, Brasil}

Em muitos países, o Enterovírus 71 (EV-71) família Picornaviridae é associado a doença de pé-mão e boca e doenças neurológicas agudas enquanto que no Brasil esse vírus está mais associado às últimas. $\mathrm{O}$ objetivo desta pesquisa foi utilizar em estudos moleculares e soroepidemiológicos, o primeiro isolamento de EV-71 obtido na região norte do Brasil. No período de janeiro de 1998 a dezembro de 2000 foram coletadas 88 amostras (44 casos de PFA) de fezes das quais, duas (2,2\%) foram positivas para EV-71 (73442/PA/99). A sequiência de nucleotídeos do gen que codifica a proteína VP1 mostrou que o isolado 73442/PA/99 foi similar às cepas de EV-71 pertencentes ao grupo B- mais próxima das norte americanas. Teste de neutralização com 389 amostras de soro colhidas no período de janeiro de 1998 a novembro de 2001, de indivíduos com idade de 0 a 15 anos residentes na cidade de Belém, Estado do Pará mostrou os seguintes resultados em relação ao isolado 73442/PA/99 e ao protótipo BrCr: 207 indivíduos $(53,2 \%)$ tinham anticorpos neutralizantes para ambos os vírus, 167 $(42,9 \%)$ não tinham anticorpos e 15 tinham anticorpos para um dos dois vírus. Somente 20,2\% das crianças com idade de 0 a 3 anos tinham anticorpos neutralizantes para EV-71, indicando que essas crianças estavam mais suscetíveis à infecção. Tanto o estudo de soroprevalência quanto o de sequenciamento da VP1 foram importantes para demonstrar a propagação e o padrão molecular do EV-71 circulante na região norte do Brasil.

\section{ACKNOWLEDGMENTS}

Our special thanks to Dr. Betty Brown who helped us several times, with opportune suggestions regarding molecular procedures.

\section{REFERENCES}

1. ABUBAKAR, S.; CHEE, H.Y.; AL- KOBAISI, M.F. et al. - Identification of enterovirus 71 isolates from an outbreak of hand, foot and mouth disease (HFMD) with fatal cases of encephalomyelitis in Malaysia.Virus Res., 61: 1-9, 1999.

2. ALEXANDER Jr., J.P.; BADEN, L.; PALLANSCH, M.A. \& ANDERSON, L.J. Enterovirus 71 infections and neurologic disease: United States, 1977-1991. J. infect. Dis., 169: 905-908, 1994.

3. BLOMBERG, J.; LYCKE, E.; AHLFORS, K. et al. - Letter: new enterovirus type associated with epidemic of aseptic meningitis and/or hand, foot, and mouth disease. Lancet., 2: 112, 1974.

4. BROWN, B.A. \& PALLANSCH, M.A. - Complete nucleotide sequence of enterovirus 71 is distinct from poliovirus. Virus Res., 39: 195-205, 1995.

5. BROWN, B.A.; OBERSTE, M.S.; ALEXANDER Jr., J.P.; KENNETT, M.L. \& PALLANSCH, M.A. - Molecular epidemiology and evolution of enterovirus 71 strains isolated from 1970 to 1998. J. Virol., 73: 9969-9975, 1999.

6. BROWN, B.A.; KILPATRICK, D.R.; OBERSTE, M.S. \& PALLANSCH, M.A. - Serotypespecific identification of enterovirus 71 by PCR. J. clin. Virol., 16: 107-112, 2000.

7. CHANG, L.Y.; LIN, T.Y.; HSU, K.H. et al. - Clinical features and risk factors of pulmonary oedema after enterovirus-71-related hand, foot, and mouth disease. Lancet, 354: 1682-1686, 1999.

8. CHOMCZYNSKI, P. \& SACCHI, N. - Single-step method of RNA isolation by acid guanidinium thiocyanate-phenol-chloroform extraction. Analyt. Biochem., 162: 156$159,1987$.

9. CHONMAITREE, T.; MENEGUS, M.A.; SCHERVISH-SWIERKOSZ, E.M. \& SCHWALENSTOCKER, E. - Enterovirus 71 infection: report of an outbreak with two cases of paralysis: a review of the literature. Pediatrics, 67: 489-493, 1981.

10. CHU, P.Y.; LIN, K.H.; HWANG, K.P. et al. - Molecular epidemiology of enterovirus 71 in Taiwan. Arch. Virol., 146: 589-600, 2001.

11. CHUMAKOV, M.; VOROSHILOVA, M.; SHINDAROV, L. et al. - Enterovirus 71 isolated from cases of epidemic poliomyelitis-like disease in Bulgaria. Arch. Virol., 60: 329$340,1979$.

12. DA SILVA, E.E.; FILLIPIS, A.M.B.; SCHATZMAYR, H.G. \& CORTES, L.C. - Evidence of enterovirus 71 infections in Brazil. Mem. Inst. Oswaldo Cruz, 85: 131-132, 1990 .

13. DA SILVA, E.E.; WINKLER, M.T. \& PALLANSCH, M.A. - Role of enterovirus 71 in acute flaccid paralysis after the eradication of poliovirus in Brazil. Emerg. infect. Dis., 2: 231-233, 1996.

14. DEAN, A.G.; DEAN, J.A.; COULOMBIER, D. et al. - EPI INFO, Version 6: a word processing, database and statistics program for epidemiology on microcomputers. Atlanta, Centers for Disease Control and Prevention, 1994

15. FERREIRA, F.C.; FILLIPIS, A.M.B. \& DA SILVA, E.E. - Partial nucleotide sequences of the 5' non-coding and VP1 regions of enterovirus 71 strains isolated in Brazil. Virus Rev. Res., 2: 153, 1997.

16. GILBERT, G.L.; DICKSON, K.E.; WATERS, M.J. et al. - Outbreak of enterovirus 71 infection in Victoria, Australia, with a high incidence of neurologic involvement. Pediat. infect. Dis. J., 7: 484-488, 1988.

17. GOMES, M.L.C.; CASTRO, C.M.O.; OLIVEIRA, M.J. \& DA SILVA, E.E. - Neutralizing antibodies to enterovirus 71 in Belém, Brazil. Mem. Inst. Oswaldo Cruz, 97: 4749, 2002.

18. HAGIWARA, A.; TAGAYA, I. \& KOMATSU, T. - Seroepidemiology of enterovirus 71 among healthy children near Tokyo. Microbiol. Immunol., 23: 121-124, 1979. 
19. HALL, T.A. - BioEdit: a user-friendly biological sequence alignment editor and analysis program for Windows 95/98/NT. Nucl. Acids Symp. Ser., 41: 95-98, 1999.

20. HAYWARD, J.C.; GILLESPIE, S.M.; KAPLAN, K.M. et al. - Outbreak of poliomyelitislike paralysis associated with enterovirus 71. Pediat. infect. Dis. J., 8: 611-616, 1989.

21. HIGGINS, D.G. \& SHARP, P.M. - Clustal: a package for performing multiple sequence alignment on a microcomputer. Gene, 73: 237-244, 1988

22. HO, M.; CHEN, E.R.; HSU, K.H. et al. - An epidemic of enterovirus 71 infection in Taiwan. Taiwan Enterovirus Epidemic Working Group. New Engl. J. Med., 341: 929-935, 1999.

23. ISHIMARU, Y.; NAKANO, S.; YAMAOKA, K. \& TAKAMI, S. - Outbreaks of hand foot, and mouth disease by enterovirus 71 . High incidence of complication disorders of central nervous system. Arch. Dis. Childh., 55: 583-588, 1980.

24. KENNETT, M.L.; BIRCH, C.J.; LEWIS, F.A. et al. - Enterovirus type 71 infection in Melbourne. Bull. Wld Hlth Org., 51: 609-615, 1974.

25. KUMAR, S.; TAMURA, K.; JAKOBSEN, I.B. \& NEI, M. - Mega 2: molecular evolutionary genetics analysis software. Bioinformatics, 17: 1244-1245, 2001.

26. LIU, C.C.; TSENG, H.W.; WANG, S.M.; WANG, J.R. \& SU, I.J. - An outbreak of enterovirus 71 infection in Taiwan, 1998: epidemiologic and clinical manifestations. J. clin.Virol., 17: 23-30, 2000.

27. LUM, L.C.S.; WONG, K.T.; LAM, S.K. et al. - Fatal enterovirus 71 encephalomyelitis J. Pediat., 133: 795-798, 1998.

28. McMINN, P.; STRATOV, I.; NAGARAJAN, L. \& DAVIS, S. - Neurological manifestations of enterovirus 71 infection in children during an outbreak of hand, foot, and mouth disease in western Australia. Clin. infect. Dis., 32: 236-242, 2001.

29. McMINN, P.; LINDSAY, K.; PERERA, D. et al. - Phylogenetic analysis of enterovirus 71 strains isolated during linked epidemics in Malaysia, Singapore, and Western Australia. J. Virol., 75: 7732-7738, 2001.

30. MELNICK, J.L.; TAGAYA, I. \& VON MAGNUS, H. - Enteroviruses 69, 70 and 71. Intervirology, 4: 369-370, 1974.

31. MELNICK, J.L. - Enterovirus type 71 infections: a varied clinical pattern sometimes mimicking paralytic poliomyelitis. Rev. infect. Dis., 6: S387-S390, 1984.

32. MELNICK, J.L. - Enteroviruses: polioviruses, coxsackieviruses, echoviruses, and newer enteroviruses. In: FIELDS, B.N.; KNIPE, D.M.; HOWLEY, P.M. et al., ed. Fields Virology. 3. ed. Philadelphia, Lippincott-Raven, 1996. v. 1, p. 665-671.

33. NAGY, G.; TAKÁTSY, S.; KUKÁN, E.; MIHÁLY, I. \& DÖMÖK, I. - Virological diagnosis of enterovirus type 71 infections: experiences gained during an epidemic of acute CNS diseases in Hungary in 1978. Arch. Virol., 71: 217-227, 1982
34. RUECKERT, R.R. - Picornaviridae: the viruses and their replication. In: FIELDS, B.N.; KNIPE, D.M.; HOWLEY, P.M. et al., ed. Fields Virology. 3. ed. Philadelphia, Lippincott-Raven, 1996. v. 1, p. 610-621.

35. SAMUDA, G.M.; CHANG, W.K.; YEUNG, C.Y. \& TANG, P.S. - Monoplegia caused by enterovirus 71: an outbreak in Hong Kong. Pediat. infect. Dis. J., 6: 206-208, 1987.

36. SCHMIDT, N.J.; LENNETTE, E.H. \& HO, H.H. - An apparently new enterovirus isolated from patients with disease of the central nervous system. J. infect. Dis., 129: 304309, 1974.

37. SHIMIZU, H.; UTAMA, A.; YOSHII, K. et al. - Enterovirus 71 from fatal and nonfatal cases of hand, foot and mouth disease epidemics in Malaysia, Japan and Taiwan in 1997-1998. Jap. J. infect. Dis., 52: 12-15, 1999.

38. SHINDAROV, L.M.; CHUMAKOV, M.P.; VOROSHILOVA, M.K. et al. Epidemiological, clinical, and pathomorphological characteristics of epidemic poliomyelitis-like disease caused by enterovirus 71. J. Hyg. Epidem. Microbiol. Immunol. (Praha), 23: 284-295, 1979.

39. SINGH, S.; CHOW, V.T.; CHAN, K.P.; LING, A.E. \& POH, C.L. - RT-PCR, nucleotide, amino acid and phylogenetic analyses of enterovirus type 71 strains from Asia. J. virol. Meth., 88: 193-204, 2000.

40. TAGAYA, I. \& TACHIBANA, K. - Epidemic of hand, foot and mouth disease in Japan, 1972-1973: difference in epidemiologic and virologic features from the previous one. Jap. J. med. Sci. Biol., 28: 231-234, 1975.

41. TAGAYA, I.; TAKAYAMA, R. \& HAGIWARA, A. - A large-scale epidemic of hand, foot and mouth disease associated with enterovirus 71 infection in Japan in 1978. Jap. J. med. Sci. Biol., 34: 191-196, 1981

42. TAKIMOTO, S.; WALDMAN, E.A.; MOREIRA, R.C. et al. - Enterovirus 71 infection and acute neurological disease among children in Brazil (1988-1990). Trans. roy. Soc. trop. Med. Hyg., 92: 25-28, 1998.

43. TRAJSTMAN, A.C. - Diagnostic tests, sensitivity, specificity, efficiency and prevalence. Aust. vet. J., 55: 289, 1979.

44. WALDMAN, E.A. - Enteroviroses emergentes de importância clínica. In: VERONESI, R. \& FOCACCIA, R. Tratado de infectologia. São Paulo, Atheneu, 1996. v. 1, p. 240-243

45. WORLD HEATH ORGANIZATION - Global programme for vaccines and immunization of polio. Manual for the virological investigation of polio. Geneva, WHO, 1996. p. 45-52.

46. YAN, J.J.; WANG, J.R.; LIU, C.C.; YANG, H.B. \& SU, I.L. - An outbreak of enterovirus 71 infection in Taiwan 1998: a comprehensive pathological, virological, and molecular study on a case of fulminant encephalitis. J. clin. Virol., 17: 13-22, 2000.

Received: 24 August 2004

Accepted: 13 December 2004 